\title{
Climatic effects on a cold stenotherm species Lepidurus arcticus (Branchiopoda, Notostraca) on the southern outreach of its distribution
} range

\author{
Tore Qvenild', Eirik Fjeld2, Arne Fjellheim 3 , Sigurd Rognerud ${ }^{4}$ and Åsmund Tysse ${ }^{5}$
}

Qvenild T, Fjeld E, Fjellheim A, Rognerud S and Tysse Å. 2018. Climatic effects on a cold stenotherm species Lepidurus arcticus (Branchiopoda, Notostraca) on the southern outreach of its distribution range. Fauna norvegica 38: 37-53.

On the Norwegian mainland, the Arctic tadpole shrimp Lepidurus arcticus is a typically alpine species mainly co-occurring with fish. The Hardangervidda mountain plateau is the main area of the southernmost $L$. arcticus populations. Here $L$. arcticus is widely distributed, especially in the central and eastern parts of the plateau. Lepidurus arcticus has a univoltine life cycle emerging from resting eggs at ice break-up and fulfil development during the short mountain summer, before they reproduce and die. The main goal in this study was to investigate the thermal thresholds for $L$. arcticus. Timing of ice break-up and the proceeding water temperature are hypothesized to constitute the primary drivers of $L$. arcticus's development and growth. Stomach analyses of brown trout is the most sensitive method for sampling $L$. arcticus, especially at low densities. Analyses of 4460 brown trout stomachs revealed that at least 400 degree-days are needed for development and growth from hatching in to adults. It is a significant gradient in climatic conditions on Hardangervidda with a coastal impact in the western part of the plateau with a three - to fourfold winter deposition compared to a dryer inland region in the east. The snow deposits have increased since the 1980s and snow rich winters have been more frequent. An additional increase is projected. This may give lower water temperature and shorter ice-free seasons. Thus, the cold western lakes could be even more hostile habitats for $L$. arcticus. During the same period, an abrupt increase in spring-summer temperatures was detected. This has improved the conditions for L. arcticus in many lakes. However, as a cold stenotherm species a further increase in temperature may be detrimental. Especially in shallow lakes in the central and eastern parts this may be a problem even without reaching critical levels by inducing life cycle mismatches.

doi: 10.5324/fn.v38i0.2598. Received: 2018-06-20. Accepted: 2018-10-27. Published online: 2018-12-19. ISSN: $1891-5396$ (electronic).

Keywords: Lepidurus arcticus, thermal threshold, degree-days, climate change

1 The Environment Agency Hedmark County, Statens hus, Parkgata 36, NO-2306 Hamar, Norway

2 Norwegian Institute for Water Research (NIVA), Gaustadaléen 21, NO-0349 Oslo, Norway

3 Uni Research Environment, Nygårdsgaten 112, NO-5008 Bergen, Norway

4 Norwegian Institute for Water Research (NIVA), NO-2312 Ottestad, Norway

5 The Environment Agency Buskerud County, Statens hus, Grønland 32, NO-3007 Drammen, Norway

Corresponding author: Tore Qvenild

E-mail:fmhetq@fylkesmannen.no 


\section{INTRODUCTION}

The Arctic tadpole shrimp Lepidurus arcticus (Pallas, 1793) has a circumpolar distribution and may occur both in shallow moraine ponds and large lakes in subarctic areas (Hessen et al. 2004). Sømme (1934) described the species as a boreoalpine relict in Scandinavia occurring at the sea-level in the Arctic, while at progressively greater altitudes further south. On the Norwegian mainland, it is a typically alpine species, mainly co-occurring with fish (Sømme 1934; Aass 1969; Borgstrøm et al. 1985; Økland \& Økland 2003). It is susceptible to fish predation (Aass 1969; Borgstrøm et al. 1985; Jeppesen et al. 2001) and acidification (Borgstrøm \& Hendrey 1976; Fjellheim \& Raddum 1990; Fjellheim et al. 2001). Lepidurus arcticus is further threatened by the spread of invasive species, especially the European minnow Phoxinus phoxinus (Linnaeus, 1758) (Borgstrøm et al. 1985). Climate change may contribute as a driver for change in life history traits and distribution (Hessen et al. 2004; Lakka 2013).

The Hardangervidda mountain plateau, later referred to as Hardangervidda, represent the southernmost outreach of $L$. arcticus (Sømme 1934; Økland \& Økland 2003; Hessen et al. 2004). Here it plays an important role in the feeding of brown trout Salmo trutta (Linnaeus, 1758) also improving the quality of the fish (Sømme 1934; Sømme 1941; Aass 1969; Qvenild 2004). Despite this, information on the biology of $L$. arcticus is in general limited and incomplete.

Lepidurus arcticus is regarded as cold stenotherm species with a narrow "temperature window" (Borgstrøm 1970; Halvorsen 1973; Klausen 2012; Lakka 2013). Global warming may thus be a problem for L. arcticus (Lakka 2013). In this context, the thermal thresholds of $L$. arcticus need more attention. The importance of temperature has been studied to some extent in shallow ponds and lakes in the Arctic (Arnold 1966; Lakka 2013), on the Norwegian mainland only in the laboratory (Klausen 2012). It seems likely that the development of $L$. arcticus highly depends on water temperature during the short growing season. Astonishing little is known of its thermal thresholds for growth and development in natural lakes, yet there exist anecdotal accounts of its importance (Sømme 1934; Aass 1969; Borgstrøm 1970; Halvorsen 1973; Borgstrøm \& Larsson 1974; Pedersen \& Scobie 1990; Simonsen \& Valderhaug 1994; Borgstrøm 2016).

There is evidence for L. arcticus to occur late if not at all in cold summers (Pedersen \& Scobie 1990; Simonsen \& Valderhaug 1994; Borgstrøm 2016: Qvenild \& Rognerud 2018). In Lake Kollsvatn in the Kvenna catchment, L. arcticus is normally seen in the fish stomachs. This was the case in the test fishing period 14 - 29 July 1988 but in the period 22 July - 6 August in 1989, L. arcticus was not recorded (Pedersen \& Scobie 1990). This year the ice break-up was severely delayed until the end of July. In this period the water temperature increased from 4 to $6^{\circ} \mathrm{C}$. In the neighbouring Lake Litlosvatn a similar situation was observed in the period 29 July - 4 August
1993 (Simonsen \& Valderhaug 1994). The lake was barely icefree at this time and only two nauplius larvae was recorded. In the cold summer 2015 no L. arcticus was noted in the fish stomachs in these two lakes, neither in August nor in the beginning of September (Borgstrøm 2016).

One of our main purposes in this study was to evaluate the thermal thresholds for development of L. arcticus in the growth period from hatching in to adults. Miller (1980) used the term cumulative degree-hours in some early pond studies (1973) of L. arcticus growth. In this study we have adapted this term to quantify the thermal energy input to reach adult sizes. We assumed the degree-days from ice break-up until the first occurrence of $L$. arcticus in the brown trout stomachs to express the lower thermal threshold.

The brown trout is an opportunistic feeder and the diet changes with food availability. Examination of stomach contents has proved to be a reliable method to evaluate the animals occurring in a lake and its surroundings, at least in relative terms (Sømme 1934; Aass 1969; Borgstrøm 1970; Fjellheim et al. 2007; Qvenild \& Rognerud 2018). Especially in the search for $L$. arcticus this method is sensitive even when $L$. arcticus occur in low densities (Fjellheim et al. 2007). Due to its big size L. arcticus is a nutrition rich and highly preferred food item (Aass 1969; Fjellheim et al. 2007; Borgstrøm 2016; Qvenild \& Rognerud 2018), hence we assume that the frequency of brown trout eating $L$. arcticus reflects the population densities of $L$. arcticus. In this study, we analysed 4460 brown trout stomachs from 235 different fishing events in six lakes. Stomach analyses also reflects the availability of other food items eaten by the brown trout, but this is not in focus in this study.

On the Norwegian mainland an increase in both air temperature $\left(\sim 1.5^{\circ} \mathrm{C}\right)$ and precipitation (an increase of $\sim 10 \%$ compared to the 1971-2000 normal) are noted since the mid1980s (Hanssen-Bauer et al. 2017). In our study these trends are projected on the regional level covering Hardangervidda. These variables are primary drivers for ice break-up and water temperature profiles through the production period with crucial impact of L. arcticus development and growth. Long-term trends in ice-free periods and water temperature are scarce in Norwegian mountain lakes. An exception is Lake Øvre Heimdalsvatn in Jotunheimen where the water temperature has been regularly monitored since 1994, the ice break-up and freeze-up since 1969 (Kvambekk \& Melvold 2010). This study has revealed a change over the period studied with a delay of the ice-break up period (6 days) and a similar delay in the freeze-up ( 9 days), i.e. the production period is nearly unchanged in this 40 years study.

On Hardangervidda snow deposition has proved to have a significant impact on ice break-up and hence, the start of the production period of L. arcticus (Borgstrøm 2001, 2016; Qvenild \& Rognerud 2018). Both snow deposition and air temperature are in progress according to the climate projections (Hanssen-Bauer et al. 2017). In the ice-free period water temperature follows those of the air (Kvambekk \& Melvold 
2010; Lindholm et al. 2015). On Hardangervidda only minor information of water temperature is available (Borgstrøm 2001; Borgstrøm \& Museth 2005; Thaulow et al. 2017). In our study a water temperature logging program was performed in 2003. In the six study lakes we aimed to establish lake specific air to water relationships for the lakes as this is needed for the implementation of the air temperature impact on the lake ecosystems.

In this study our main goal was to evaluate the lower thermal threshold for development of L. arcticus in the growth period from hatching in to adults. The ice break-up and the water temperature in the production period are crucial. Both are highly variable on Hardangervidda. In progress of the ongoing global warming this may impact the populations of $L$. arcticus in different ways.

\section{MATERIAL AND METHODS}

\section{Study area}

Hardangervidda is the largest peneplain (eroded plain) in Europe (Anonymous 1974). Here, brown trout is to a large extent the only allopatric fish species. In a very few lakes, Arctic char Salvelinus alpinus (Linnaeus, 1758) occur (3.5\% of 930 named lakes in 27 catchments), mainly due to stockings in the $20^{\text {th }}$ century (Qvenild 2004). The European minnow Phoxinus phoxinus has been introduced to $8.9 \%$ of the lakes since the 1970s (Qvenild 2004). The brown trout are of good size and quality and support a number of traditional fisheries (Sømme 1941; Qvenild 2004).

The Hardangervidda landscape is characterized by barren, treeless moorland interrupted by numerous pools, lakes, rivers and streams. The central part of this peneplain is a National Park. There are large differences between the western and eastern sides, which are dominated by rocky terrain and expanses of bare rock, and flatter and more vegetated areas, respectively.

The study lakes are situated 1076-1313 m a.s.l. (Figure 1). The lakes are medium sized with surface areas $0.3-3.32 \mathrm{~km}^{2}$ and shallow with mean depth $2.6-10.0 \mathrm{~m}$ (Table 1). The brown trout populations in the study lakes are all allopatric. The populations are thin and with minor variation in stock densities. However, the 1997 year-class was extremely numerous giving a sharp rise in stock densities in the period 2003-2007, especially in Lake Sandvatn (Qvenild \& Rognerud 2018). The main crustacean food items in Lake Sandvatn are L. arcticus, Gammarus lacustris G.O. Sars, 1863 and Eurycercus lamellatus A.F.M (Qvenild \& Rognerud 2018). In the period 2001-2016 the three crustaceans contributed with 60-90 volume percent in most of the years (Qvenild \& Rognerud 2018). In a great number of lakes at the central and eastern part of the plateau these species dominate in the diet of the brown trout.

Field studies were conducted in the period 2001-2016 in the five lakes in the Kvenna catchment (Sandvatn, Fjellsjåen,
Dargesjåen, Kringlesjåen, Blånuttjørnane), mainly to improve fishery management strategies (cf. Appendix 1 for details). This implied the variation in year class strength and the adjustment of exploitation rates to the resulting standing crop. To put the results into a spatial context, water temperature and seasonal occurrence of L. arcticus was compared with Lake Dragøyfjorden in the Hein catchment (cf. Appendix 1 for details) where a monitoring program of water temperature and ice-off started in 2003. In the headwaters upstream Lake Dragøyfjorden a liming mitigation program was initiated in 1994 to improve the conditions for the rare "fine spotted" brown trout (Fjellheim et al. 2001). This variant is also a part of the brown trout population in Lake Dragøyfjorden where it constitutes $26 \%$ of the commercial catches (Herman Stakseng, pers. comm.). No stockings have been performed in the study lakes except some stockings of "fine spotted" brown trout in Lake Dragøyfjorden. These stockings have proved to give an insignificant contribution to the catches.

Lake Dragøyfjorden comprises bedrock of Precambrian gneisses and granites covered by thin or no moraine with sparse or no vegetation giving a dilute water quality $(\mathrm{pH} 6.13$, Calcium concentration $0.64 \mathrm{mg} \mathrm{L}^{-1}$ ). In the other five lakes the bedrock is much the same but with a thicker moraine and a richer vegetation. This gives slightly improved water qualities $(\mathrm{pH}$ range 6.33-6.72, Calcium concentration range 1.01-2.03 $\mathrm{mg} \mathrm{L}^{-1}$ ).

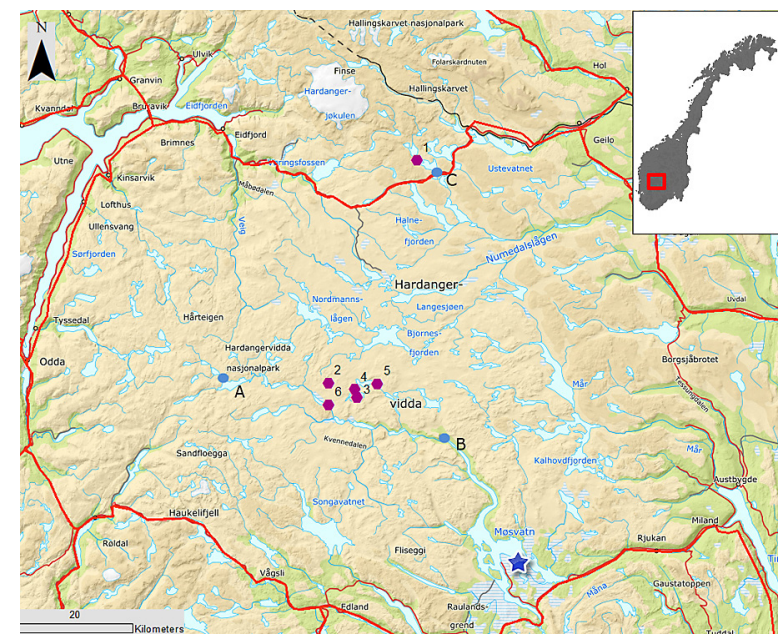

Figure I. Map of the study lakes on Hardangervidda: 1) Dragøyfjorden, 2) Blånuttjørnane, 3) Kringlesjåen, 4) Dargesjåen, 5) Fjellsjåen and 6) Sandvatn. Vital statistics for the lakes are given in Table 1. Snow depth are measured by the hydro power companies at Litlos (A), Argehovd (B) and Krækkja (C). The climate station Møsstrond $\left(59.8397^{\circ} \mathrm{N}, 8.1785^{\circ} \mathrm{E}\right)$ are indicated with a blue star. The Norwegian Mapping Authority CC BY 4.0. 
Table I. Vital statistics of the six study lakes. The statistics are given by the Norwegian Water Agency (NVE) and computed by the NEVINA procedure (NVE Atlas, www.nve.no), except for mean and maximum depth (own data). The lake area is included in the catchment which is computed with the outlet as set point in the NEVINA procedure. Lake number refers to the numbers given in Figure 1.

\begin{tabular}{llllllllll}
\hline No & Lake & Altitude $\mathrm{m}$ a.s.l. & ${\text { Area } \mathrm{km}^{2}}^{\circ} \mathrm{N}$ & ${ }^{\circ} \mathrm{E}$ & Catchment km & Mean depth $\mathrm{m}$ & Max depth $\mathrm{m}$ & Retention time days \\
\hline 1 & Dragøyfjorden & 1180 & 3.32 & 60.4533 & 7.7026 & 35.60 & 10.0 & 42 & 399 \\
2 & Blånuttjørnane & 1313 & 0.31 & 60.0883 & 7.5020 & 3.70 & 6.1 & 31 & 179 \\
3 & Kringlesjåen & 1258 & 0.71 & 60.0707 & 7.5978 & 3.20 & 4.5 & 14 & 345 \\
4 & Dargesjåen & 1209 & 0.64 & 60.0835 & 7.5866 & 15.70 & 4.7 & 15 & 66 \\
5 & Fjellsjåen & 1197 & 2.31 & 60.0958 & 7.6566 & 37.40 & 8.1 & 26 & 175 \\
6 & Sandvatn & 1112 & 1.56 & 60.0546 & 7.5111 & 288.20 & 2.6 & 13 & 4 \\
\hline
\end{tabular}

\section{Climatic conditions}

Precipitation and air temperature are primary variables in the study of the ongoing global warming process (Hanssen-Bauer et al. 2017). Both variables are reflected in the thermal status of the lakes as water temperature and length of production period (Kvambekk \& Melvold 2010).

Precipitation normally accumulates as snow through winter in this high mountain areas and snow depth in April is used as the snow accumulated in separate years. We have yearly snow depth data from three stations: Litlos, Argehovd and Krækkja (cf. Figure 1). From Litlos (1931-2017) and Argehovd (19432017) in the Kvenna catchment we have received data from the hydro power company Øst-Telemarkens Brukseierforening. For the Dragøyfjorden area we have data from Krækkja (1970-2017) some kilometres downstream Lake Dragøyfjorden where the snow depth is regularly measured by the hydro power company Numedal-Laugens Brugseierforening.

Ice break-up is essential for starting up the production period and on Hardangervidda this primary variable seems highly dependent of snow deposition (Borgstrøm 2016). To set this date satellite observations may be helpful, but initially such observations were hardly available. In Lake Dragøyfjorden photographing of the lake at 18 June started up in 2003 and this program are followed every year thereafter. Two examples are shown, a complete ice-free lake in 2013 and a complete ice-covered lake in 2015 (Figure 2). Most of the years ice-break has been in progress at 18 June. From the photographs three observers set the percent ice-cover at 18 June independently (Figure 3). In Lake Dragøyfjorden the water temperature was logged continuously, hence the water temperature can be set accurately at 18 June when the lake was photographed.

The year to year temperature fluctuations are crucial for studying the regional impact of global warming. To evaluate the long-term trend, we have compared local climate stations with the "Vestlandet-series" (Nordli et al. 2003). This series was reconstructed for the period 1734-2003 for western Norway. The "Vestlandet" series was prolonged to 2017 (eKlima, www. met.no).

A water temperature logging program was performed in three of the study lakes with yearly logging since 2003 (Sandvatn, Dargesjåen and Dragøyfjorden). The other lakes (Blånuttjørnane, Kringlesjåen and Fjellsjåen) were only fragmentarily monitored. Daily mean water temperatures were recorded by use of temperature loggers (Hobo UA-00264), mainly at 1-2 $\mathrm{m}$ depth in the littoral zone. In Lake Dragøyfjorden two logger stations were established, one in the outlet $(\sim 0.5 \mathrm{~m})$ and one at $2 \mathrm{~m}$ depth.

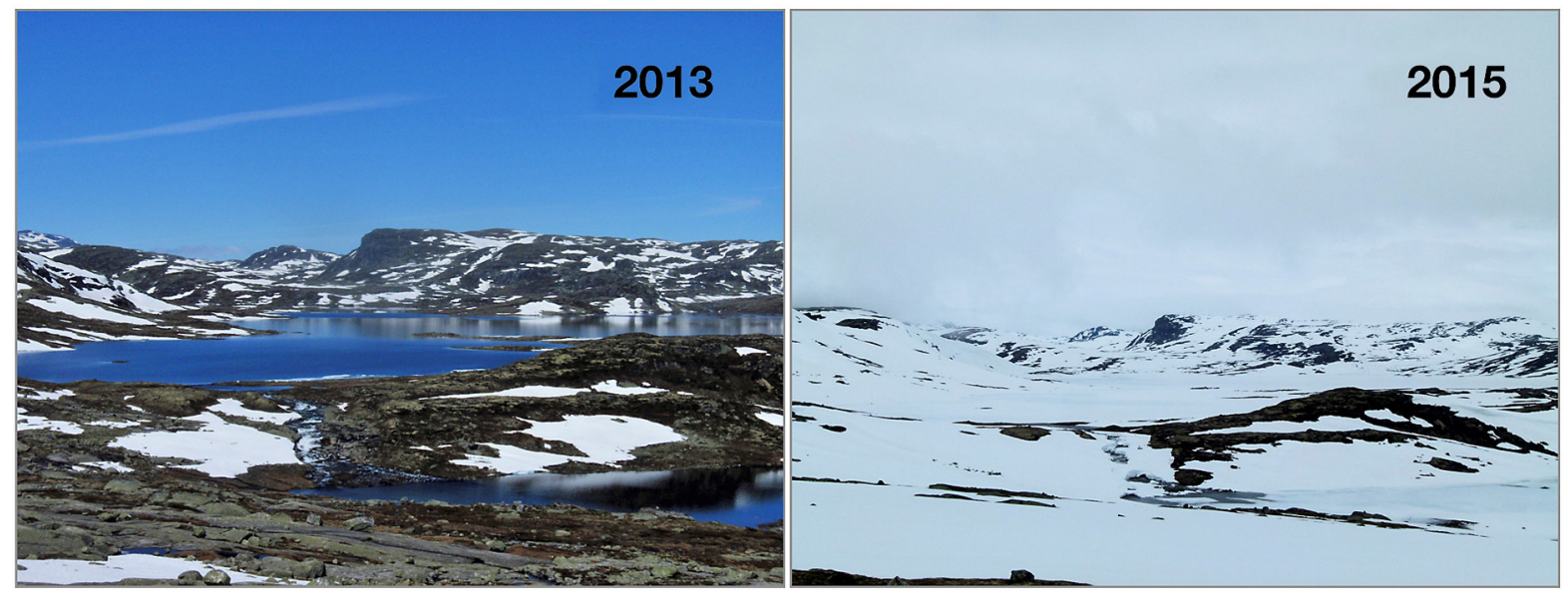

Figure 2. Lake Dragøyfjorden 18 June in 2013 and 2015. In 2013 the lake is complete ice-free, in 2015 complete ice-covered. Photo: Georg Gjøstein. 


\section{Computation of thermal energy demand of Lepidurus arcticus}

Fish stomachs were sampled from the six study lakes in the period 2003-2016 (Table 2). In total, 4460 brown trout $\geq 250$ $\mathrm{mm}$ from 235 fishing events were analysed (cf. Appendix 1 for details). They were analysed in the field and fragments and/ or small $L$. arcticus may be overviewed. By comparing the number of fish containing $L$. arcticus with the total of stomachs analysed, the frequencies of fish with $L$. arcticus eaten (in $\%)$ were calculated. This is a fairly accurate measure and we assume this reflects the availability of $L$. arcticus, i.e. more of the brown trout succeed in finding this preferred food item when the densities are high.

From the fish statistics of 235 dated fishing events, the frequency of $L$. arcticus in the stomachs can be given at the date of fishing and the respective degree-days computed from the water temperature files.

Table 2. The number of stomachs sampled from the six study lakes. In total 4460 brown trout stomachs were examined in 235 dated fishing events (for details cf. Appendix 1).

\begin{tabular}{llllll}
\hline & & No of & No fish & No fish with \\
Lake & Period & events & $\geq 25 \mathrm{~cm}$ & L. arcticus & Freq. \% \\
\hline Blånuttjørnane & 2004 & 2 & 21 & 2 & $10 \%$ \\
Dargesjåen & $2003-2012$ & 8 & 145 & 45 & $31 \%$ \\
Dragøyfjorden & $2006-2016$ & 164 & 2863 & 731 & $26 \%$ \\
Fjellsjåen & $2006-2012$ & 10 & 312 & 119 & $38 \%$ \\
Kriglesjåen & 2004 & 2 & 57 & 36 & $63 \%$ \\
Sandvatn & $2004-2016$ & 49 & 1062 & 59 & $6 \%$ \\
\hline Total & & 235 & 4460 & 992 & $22 \%$ \\
\hline
\end{tabular}

There is evidence for $L$. arcticus to occur in its first larvae stages the days after ice break-up (Borgstrøm 1970; Halvorsen 1973; Simonsen \& Valderhaug 1994). Hence, we have used $4^{\circ} \mathrm{C}$ as a set point for the period of $L$. arcticus to grow from the larval stage into adults available as significant food items for the brown trout. In the computation of degree-days daily averages are integrated from the date with a water temperature approximately $4^{\circ} \mathrm{C}$.

In this context, the frequency of fish eating L. arcticus was computed for brown trout $\geq 250 \mathrm{~mm}$ because the gill nets used in the commercial fishery in Lake Dragøyfjorden (35, 39 and 45 $\mathrm{mm}$ mesh size), mainly catch fishes $\geq 250 \mathrm{~mm}$. In the test fishing lakes (Blånuttjørnane, Dargesjåen, Fjellsjåen. Kringlesjåen and Sandvatn) 3641 brown trout caught in August-September 2003-2016 were analysed. The frequency of L. arcticus in the stomachs showed a significant increase with fish size with an abrupt change at about $300 \mathrm{~mm}$ (Figure 3). This implies that the size group studied is the most relevant.

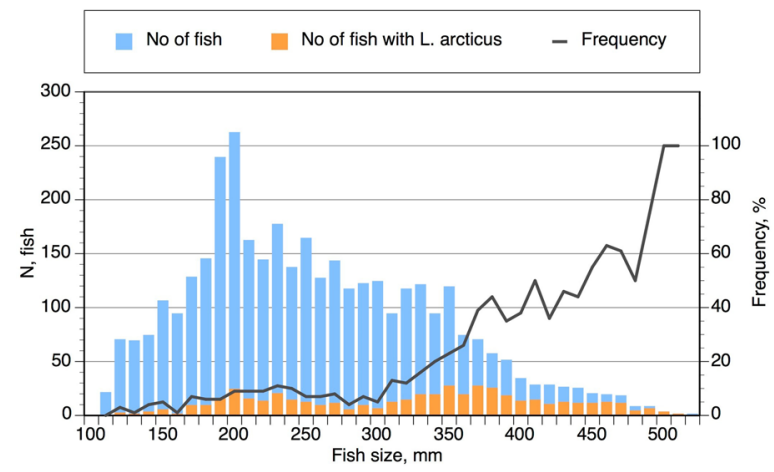

Figure 3. Frequency $\%$ of brown trout with Lepidurus arcticus in the stomach content. In the test fished lakes (Blånuttjørnane, Dargesjåen, Fjellsjåen. Kringlesjåen and Sandvatn) 3641 brown trout caught in August-September 2003-2016 were analysed.

\section{RESULTS}

\section{Climatic conditions on Hardangervidda}

The winter deposition varies substantial from west/southwest to the eastern part on Hardangervidda. In the southwestern part of the plateau the winter deposition is as high as $1151 \mathrm{~mm}$ (in the Austdølo/Ljoso catchment), in the east the winter deposition is as low as $292 \mathrm{~mm}$ (Uvdalselvi catchment), i.e. a fourfold increase along this gradient. These values are computed by the NEVINA procedure (NVE Atlas, www.nve.no). At the central part of the plateau it is at an intermediate level (approximately $500 \mathrm{~mm}$ ).

The west to east gradient in snow deposition is reflected in the Kvenna catchment with a mean snow depth at Litlos at 187 $\mathrm{cm}$ compared to only $91 \mathrm{~cm}$ at Argehovd (Figure 4). At Litlos we found an emerging positive trend in snow depth (Mann Kendall test: $n=83, \tau=0.138, p=0.06$; linear regression, snow-depth on year: $\mathrm{Y}=0.57 \cdot \mathrm{X}-938.3, \mathrm{p}=0.04)$. Year to year variations may be substantial. At Litlos the snow depth shows variations in the period 1930-2017 from 70-324 cm (mean $187 \mathrm{~cm}, \mathrm{SD} \pm 64 \mathrm{~cm}$ ). Since 1930, winters with snow depth $>250 \mathrm{~cm}$ were noted at 15 occasions, 73\% were from the period 1989-2017. The Krækkja station is at an intermediate level. Here, the snow depth shows variations in the period 1971-2017 from 55-230 cm (mean 121 $\mathrm{cm}, \mathrm{SD} \pm 35 \mathrm{~cm})$. The snow deposition follows that of Litlos $\left(\mathrm{r}^{2}=\right.$ 0.67). There is no significant trend in snow depth at Argehovd. Since the mid-1980s it has been an increased variation in snow deposition for all three stations, as can be observed in the broader confidence intervals around the smoothing curves (cf. Figure 4).

After year 2000 the spring-summer temperatures at Bergen meteorological station during the years 2000-2017 (12.6 \pm $0.8^{\circ} \mathrm{C}$ ) were significantly elevated compared to the $1961-1990$ normal $\left(11.7 \pm 0.6^{\circ} \mathrm{C}\right)$ (Wilcoxon signed rank; $\mathrm{p} \leq 0.001$ ). The Bergen instrumental series correlates well with the local station Møsstrond $\left(r^{2}=0.76, p<0.0001\right)$, Bergen being $5.3^{\circ} \mathrm{C}$ warmer (Figure. 5). The same phenomenon can thus be observed at Møsstrond $\left(7.1 \pm 0.7^{\circ} \mathrm{C}\right.$ vs. $\left.6.3 \pm 0,6^{\circ} \mathrm{C}, \mathrm{p}=0.001\right)$. 


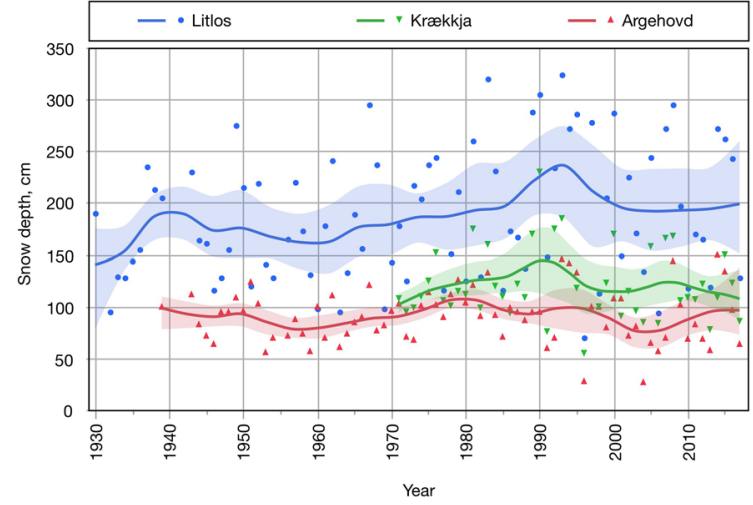

Figure 4. Snow depth in April at Litlos and Argehovd in the Kvenna catchment (data form Øst-Telemarkens Brukseierforening) and from Krækkja in the Dragøyfjorden area (data from NumedalsLaugens Brugseierforening). Smoothing curves (cubic splines, $\lambda$ $=0.005$ ) with $95 \%$ confidence intervals (bootstrapped) show the main trends.

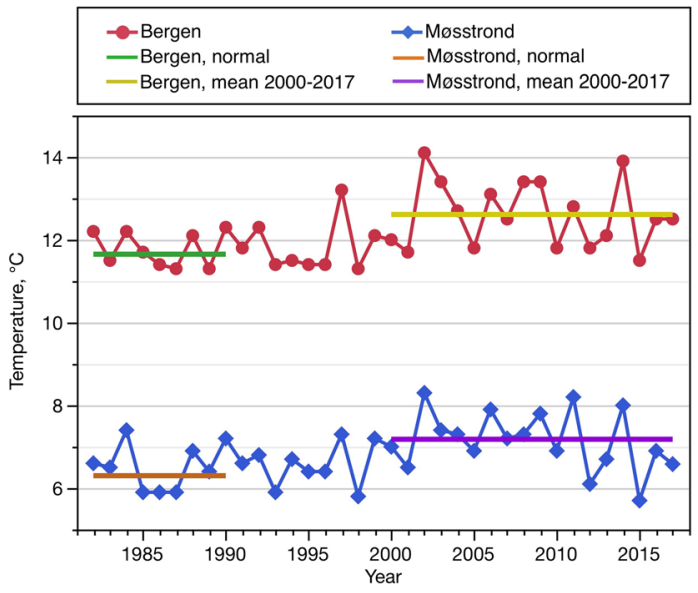

Figure 5. The spring-summers temperature (April - August) at Bergen meteorological station during the years 2000-2017 (12.6 $\left.\pm 0.8^{\circ} \mathrm{C}\right)$ was significantly elevated compared to the $1961-1990$ normal $\left(11.7 \pm 0.6^{\circ} \mathrm{C}\right)$ (Wilcoxon signed rank; $\left.\mathrm{p}=<0.001\right)$. The same phenomenon can also be observed at Møsstrond $\left(7.1 \pm 0.7^{\circ} \mathrm{C}\right.$ vs. $\left.6.3 \pm 0.6^{\circ} \mathrm{C}, \mathrm{p}=0.001\right)$.

\section{Snow depth, ice break-up and snow melting effects}

Snow depth and air temperature are the main drivers to ice break-up and water temperature regimes in the lakes.

In Lake Dragøyfjorden, the water temperatures were 0.1$1.0^{\circ} \mathrm{C}$ at a completely ice-covered lake (Figure 6). In a complete ice-free lake, the water temperature had increased to $4-5^{\circ} \mathrm{C}$. At 18 June during 2004-2017, the temperature in the outlet were slightly warmer than at $2 \mathrm{~m}$ depth with a mean difference $( \pm \mathrm{SE})$ of $0.4 \pm 0.1^{\circ} \mathrm{C}$ (t-test: $\mathrm{p}=0.04$ ). However, at $50 \%$ ice-cover the difference was only $0.2 \pm 0.1^{\circ} \mathrm{C}$. Time from the first break up to an ice-free lake varied from 8 to 24 days (mean 15 days). The earliest 50\% ice-free date was 11 June 2013, the latest 13 July 2015 (median date 19 June).

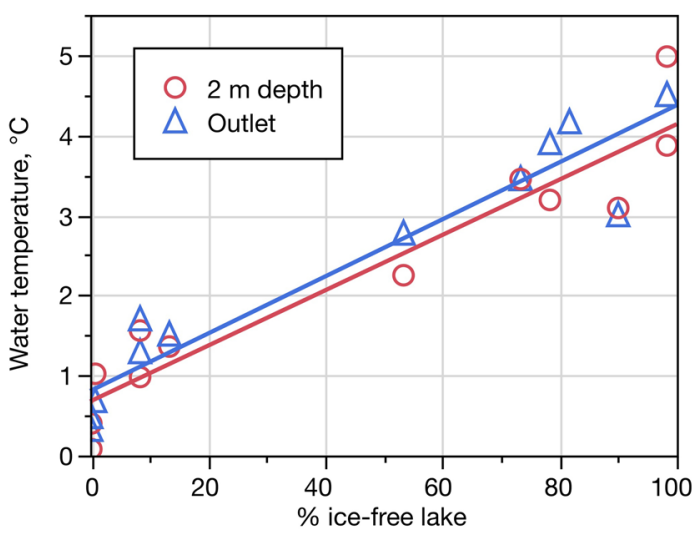

Figure 6. Water temperature and percent of ice-free lake 18 June 2004-2017 in Lake Dragøyfjorden in the outlet $\left(\mathrm{r}^{2}=0.91\right)$ and at $2 \mathrm{~m}$ depth $\left(\mathrm{r}^{2}=0.87\right)$. At almost ice-free lake $(>80 \%$ ice-free $)$ the water temperature in the outlet is $3-5^{\circ} \mathrm{C}$. The mean $( \pm \mathrm{SE})$ difference in temperature at $2 \mathrm{~m}$ depth is $0.4 \pm 0.1^{\circ} \mathrm{C}$ lower than in the outlet $(\sim 0.5 \mathrm{~m})$.

If the water temperature is approximately $4^{\circ} \mathrm{C}$ at the ice break-up, Lake Sandvatn and Lake Dargesjåen will be ice-free in mean 18 June and 14 June, respectively. This coincides well with the subjective set ice break-up dates by a local observer in Lake Sandvatn (Halvor Nordjordet, pers. comm.). Ice-break up varies from 13 June (2004) to 6 July (2015) in Lake Sandvatn. In most years Lake Dargesjåen is ice-free some days earlier.

In years with heavy snowfalls, the ice-break up may be delayed with up to 40 days at the most extreme conditions (Figure 7). In addition to the snow deposition, a cold spring may interfere on the ice break-up as demonstrated in 2012 and 2015 when the weather was cold with a delayed ice break-up by approximately 10-15 days. At low deposits of snow at approximately $80 \mathrm{~cm}$, the ice break-up is seen in the period 17-24 June (day numbers 167-174). With snow depth at

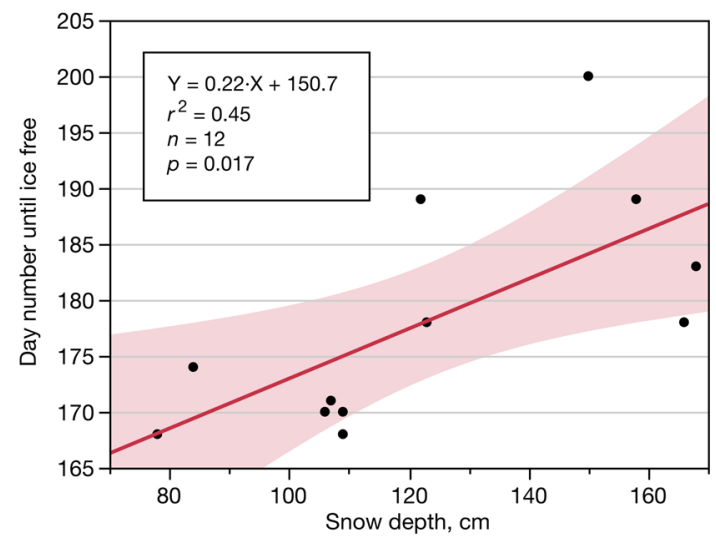

Figure 7. Time of ice-break up at different levels of snow depth in Lake Dragøyfjorden $\left(r^{2}=0.45\right)$. In 2012 and 2015 the weather was cold and the ice break-up was delayed by approximately 10-15 days. If these two years are skipped the correlation is improved $\left(\mathrm{r}^{2}=0.64\right)$. 
approximately $160 \mathrm{~cm}$ the ice break-up will be at 30 June-10 July (day numbers 180-189) respectively. Day numbers are counted from 1 January in respective years.

Lake Sandvatn has a big catchment compared to the other lakes. The snow deposition in the headwater areas was also at a significantly higher level. This will strongly influence water temperature in the lake. The snow melting effect in Lake Sandvatn was evaluated by comparing the water temperature profiles with the profiles in Lake Dargesjåen, situated in a tributary to Kvenna not influenced by the heavy snow falls in the headwater of the main river. In years with heavy snow falls, the water temperature in Lake Sandvatn may be significant lowered in June/ July and even in August compared to Lake Dargesjåen. In years with low snow deposits the water temperature revealed coinciding profiles in the two lakes $(2003,2004,2006,2010$ and 2017). In the remaining 10 years of our series we had significant snow melting effects in Lake Sandvatn. Snow depth at approximately $160 \mathrm{~cm}$ at Litlos usually gives snow melting effects. Snow depths $>160 \mathrm{~cm}$ have occurred at 53 occasions since 1930. In the years prior to and after 1985 this event was observed in $54 \%$ and $67 \%$ of the years, respectively. Hence, snow melting effects are currently more frequently seen.

The water temperature logging series revealed that mean water temperatures (1 July - 15 September) followed those of the air (1 July - 15 September). Diurnal water temperatures variations were modest compared to air. To compute lake air temperature, we used air temperature at Møsstrond climate station $(977 \mathrm{~m}$ a.s.l.) adjusted for altitude with a lapse rate $0.6^{\circ} \mathrm{C}$ per $100 \mathrm{~m}$ (Kvambekk \& Melvold 2010). The air to water temperature regressions are lake specific. The lake water temperature was on average $2.0^{\circ} \mathrm{C}$ warmer than the corresponding air temperatures in the six study lakes. Lake Sandvatn and Lake Dragøyfjorden is lower than the mean, Lake Sandvatn with heavy snow deposits and Lake Dragøyfjorden with its large volume of water.

\section{Water temperature and development of Lepidurus arcticus}

The earliest record of adult $L$. arcticus in fish stomachs was from Lake Dragøyfjorden at 363 degree-days (7 August 2016). When approximately 400 degree-days are achieved the frequency of brown trout eating $L$. arcticus increase quickly (Figure 8), hence we assume a heat amount of 400 degree-days as a lower thermal threshold. In normal years this level will be reached at 5 August (earliest 24 July 2009, latest 4 September 2015) in Lake Dragøyfjorden compared to 1 August in Lake Sandvatn (earliest 22 July 2006, latest 20 August 2012). In the warmer Lake Dargesjån this threshold will be reached at 23 July (earliest 16 July, latest 8 August).

The highest frequencies of $L$. arcticus in the brown trout stomachs were noted at 800-899 degree-days. This coincides with mid-August to mid-September, the period normally seen to be the most important period for the brown trout eating $L$. arcticus. In cold summers like 2007, 2012 and 2015 this level was never achieved.

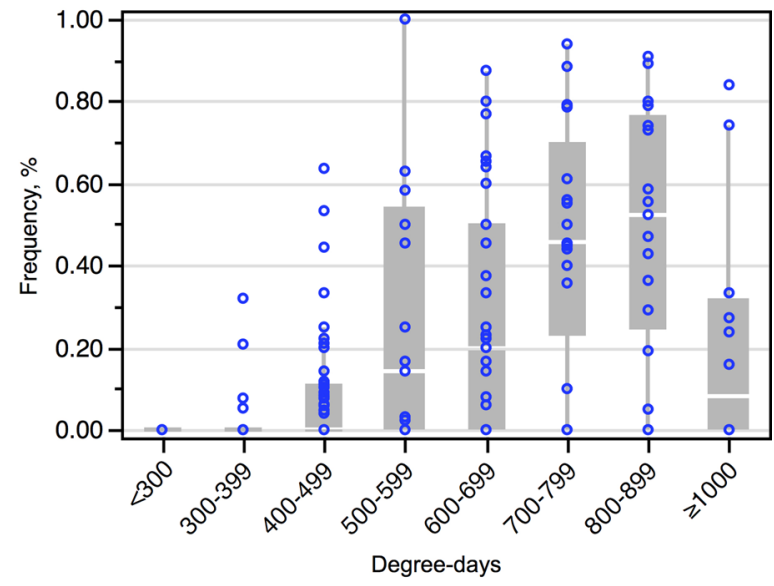

Figure 8. Box plot of the frequency of Lepidurus arcticus in brown trout stomachs for the 235 fishing events. Lepidurus arcticus are not noted in the brown trout stomachs before approximately 400 degree-days. The frequency is at its highest level after 800-899 degree-days and then ceasing. The median is illustrated with a horizontal line, the box represents the interquartile range (IQR) and the whiskers are drawn to the furthest point within $1.5 \times \mathrm{IQR}$ from the box.

\section{DISCUSSION}

Alpine ecosystems are expected to face pronounced responses to global warming and increased temperatures and an extended growing season have already been observed in lake ecosystems worldwide (Lindholm et al. 2012). On the Norwegian mainland an increase in both air temperature and precipitation are noted since the mid-1980s (Hanssen-Bauer et al. 2017). A similar increase is seen on Hardangervidda. This may have crucial effects on the alpine aquatic systems as they interfere with the derived variables of water temperature and the length of the growing season. Our main goal was to identify thermal thresholds which may shed light on the possible effect of global warming to $L$. arcticus. On Hardangervidda a substantial west to east gradient in climatic conditions may give different responses to $L$. arcticus to the projected trends towards 2100 (Hanssen-Bauer et al. 2017).

\section{Thermal energy demands for development and growth in Lepidurus arcticus}

Lepidurus arcticus is regarded as one of the most important food items for the brown trout in high mountain lakes, especially on Hardangervidda (Dahl 1917; Sømme 1934; Sømme 1941; Økland \& Økland 2013; Borgstrøm 2016). However, it occurs in highly variable numbers as experienced in Lake Sandvatn where $L$. arcticus as a mean comprised 13 volume percent of the stomach contents in the 16 years series (Qvenild \& Rognerud 2018). Six of the years L. arcticus was not or barely not, recorded. The test fishing was performed in mid-August every year. Lepidurus arcticus has proved to be very susceptible to 
fish predation and in Lake Sandvatn this was obviously the case in 2006-2007 when the brown trout population was dense. In the cold summer 2015 the brown trout population was at a normal level, nevertheless $L$. arcticus was not noted in the stomachs. This was also experienced in two headwater lakes at some similar occasions (Pedersen \& Scobie 1990; Simonsen \& Valderhaug 1994; Borgstrøm 2016). In a reservoir L. arcticus grew faster in a shallow warmer area compared to the deeper and colder part, indicating water temperature to be a primary driver to development and growth (Borgstrøm 1970).

To express these addictions we used the term degreedays, i.e. at high temperatures $L$. arcticus needs a short period to develop and vice versa. The daily mean temperatures were integrated from "hatching" to "adults". Hatching is normally assumed to follow near to snow melt and ice break-up (Borgstrøm 1970; Miller 1980; Fjellheim et al. 2007; Lakka 2013). On Hardangervidda early life stages of $L$. arcticus are observed in the initial period after ice break-up (Borgstrøm 1970; Halvorsen 1973; Simonsen \& Valderhaug 1994). In Lake Dragøyfjorden the water temperature was $4-5^{\circ} \mathrm{C}$ when ice-free, then it increased quickly in most years. In Lake Litlosvatn the temperature was $4-6^{\circ} \mathrm{C}$ initially to ice break-up (Simonsen \& Valderhaug 1994). This was confirmed in Lake Sandvatn and Lake Dargesjåen as well in the years with continuing water temperature logging. Hence, we used $4^{\circ} \mathrm{C}$ as a set point for the growth period of $L$. arcticus although all the eggs do not hatch simultaneously (Sømme 1934). The set point temperature is not crucial to the thermal threshold computations as the water temperature normally increase fast and the thermal energy accumulated in the initial phase is small.

No measurements of size or maturation of $L$. arcticus exists from the stomach analyses. In this study we have defined $L$. arcticus as adult when it is detected in the stomachs. Earlier stages of $L$. arcticus may contribute to the brown trout feeding in late June / early July (Borgstrøm 1970). However, this was experienced in a reservoir but are not noted from natural lakes on Hardangervidda.

In 132 of the fishing events (56\%), no L. arcticus was noted in the fish stomachs. In our study the period with negative findings of $L$. arcticus covered 17 June (2004) - 30 September (2011), i.e. most of the production period. As L. arcticus has grown into adults they will be more exposed to brown trout predation. The 104 fishing events (44\%) with positive findings of L. arcticus covered a period 27 July (2009) - 2 October (2006). No L. arcticus was noted in the fish stomachs in our study lakes until 363 degree-days were achieved (7 August 2016 in Lake Dragøyfjorden). At 400 degree-days an abrupt increase reflected the recruitment into adults, hence this level may be set as the lower thermal threshold.

As $L$. arcticus recruited into adults the frequency of $L$. arcticus in the stomachs increased with degree-days until a level of approximately 900 degree-days, thereafter the frequency decreased. We assume this to be a result of predation and the natural cease off process in L. arcticus (Sømme 1934;
Aass 1969; Borgstrøm 1970; Lien 1978). In cold summers like 2007, 2012 and 2015 these levels were never achieved. This may have reduced the egg production. However, no negative effects could be traced the following years. The reduced egg production may have been counteracted by a lowered predation rate.

This development patterns reflects the variability seen in natural populations due to year specific climatic conditions. In our study lakes 54 fishing events were performed before 27 July with no records of $L$. arcticus. Hence, no early records of L. arcticus are documented in our material. Early findings of adult $L$. arcticus are not noted on Hardangervidda where $L$. arcticus normally are seen in late-July/ early-August (Dahl 1917; Sømme 1941; Borgstrøm 2016). In the warm summer 2006 the necessary 400 degree-days were achieved 2 August in Lake Dragøyfjorden. The lake was fished in the period 2-8 August with a positive finding 3 August.

In the cold 2015, L. arcticus contributing to brown trout feeding was insignificant. In Lake Sandvatn $L$. arcticus was not noted in mid-August in 2015 (8-14 August). The water temperature reached 400 degree-days 23 August, hence $L$. arcticus should presumably be present to some extent in late season. In Lake Dragøyfjorden L. arcticus was noted 9 September this year after 401 degree-days.

\section{Long-term trends in climate conditions on Hardangervidda}

Annual mean precipitation on the Norwegian mainland has increased since 1900 and in particular since the 1980s (HanssenBauer et al. 2017). In the western part on Hardangervidda the same increasing trend is evident, especially when focusing on extreme winters. Prior to 1985 , only four winters with snow deposition $>250 \mathrm{~cm}$ was noted at Litlos (8\%), compared to eleven events in the proceeding period (34\%). A further increase in snow rich winters may impact on the ice breakup dates. In Lake Litlosvatn in the Kvenna River, Borgstrøm (2001; 2016) revealed that ice break-up could be predicted most parsimoniously by snow depth in April. However, ice breakup is also influenced by the spring-summer temperatures. Protracted cold spring-summers in 2012 and 2015 impeded the ice break-ups those years. In 2018 high spring temperatures caused an early ice break-up following a snow rich winter (not shown in our dataset). Occasions like this may counteract increased snow falls.

Snow rich winters in the western part of Hardangervidda (i.e. Litlos) also mean snow rich winters at the central part of the plateau (i.e. Lake Dragøyfjorden, $r^{2}=0.64$ ) but at a lower level. With even less snow deposition in the east, this effect is diminished in this part of the plateau.

A spring-summer reconstruction showed an air temperature increase in the $20^{\text {th }}$ century (Nordli et al. 2003). The increase in temperature often seems to have occurred in abrupt shifts, as in the 1810s and the 1920s. Since the last shift the temperature has remained high, but it had not increased above the maximum of the 1940s until recently. The average spring- 
summer temperatures after 2000 at Møsstrond climate station is significantly elevated compared to the 1961-1990 normal (Qvenild \& Rognerud 2018). On the Norwegian mainland the increase in temperature has been very pronounced for the past 40 years and projections toward 2100 indicate a further warming for all seasons (Hanssen-Bauer et al. 2017).

Water temperature is a basic physical parameter, influencing biota directly. The change in the air temperature regime may also be reflected in elevated water temperatures in river and lakes. However, a regional climatic forcing will not necessarily induce a common water temperature response, due to the influence of catchment properties on water temperature regimes. This was clearly experienced in Lake Øvre Heimdalsvatn and the neighbouring catchment River Leirungsåi (Kvambekk \& Melvold 2010), as it is in our study in River Kvenna. In the ice-free period the water temperature was on average approximately $3.0^{\circ} \mathrm{C}$ warmer than the projected lake air temperature (Kvambekk \& Melvold 2010), i.a. about the same as in Lake Dargesjåen $\left(2.7^{\circ} \mathrm{C}\right)$.

There is an inertia to spring warm-up in large catchments with heavy deposits of snow as seen in the River Leirungsåi (Kvambekk \& Melvold 2010). In Lake Sandvatn a similar snow melt effect has been recorded in $67 \%$ of the summers, giving $1^{\circ} \mathrm{C}$ higher water temperature compared to air temperatures. In this series opposite situations exist with higher air temperatures compared to water. This seems to be most prominent in cold summers (2007, 2012 and 2015).

Snow depths $>160 \mathrm{~cm}$ at Litlos have triggered snow melting effects in Lake Sandvatn and the frequency of winters above this level has increased significantly. Thus, Lake Sandvatn and other lakes in the main River Kvenna will be influenced by the snow deposition in the upper and western part of the catchment resulting in lower temperatures compared to other central and eastern lakes. Until the end of the century, the projection indicates a further increase in annual precipitation (HanssenBauer et al. 2017).

\section{Changing climatic conditions - what will the consequences to Lepidurus arcticus be?}

On Spitsbergen Lakka (2013) stated that water temperature had a major impact on the hatching time, growth and sexual maturity in L. arcticus. This is also indicated from the Norwegian mainland (Sømme 1934; Aass 1969; Borgstrøm 1970; Borgstrøm 2016). Lepidurus arcticus may succeed in fulfilling development until maturation and egg laying even at low temperatures given the necessary time.

A deficit in the thermal balance seen in years with heavy snow falls, late ice break-up and/or cold summers may reduce the egg production or egg laying may completely cease. An increased frequency of periods with snow rich winters, cascading effects may be expected to give life cycle mismatches due to low or no egg production. Thus, the cold western lakes could be even more hostile habitats for $L$. arcticus in the future.

Air temperature projection reveal a further increase in this century (Hanssen-Bauer et al. 2017). To some extent this may have positive impact on lake productivity if the summer temperature does not reach critical levels. Water temperatures above $19-20^{\circ} \mathrm{C}$ seems to be lethal to L. arcticus (Arnold 1966; Klausen 2012; Lakka 2013). In deeper lakes the water temperature seldom reaches such critical levels for more than a few days and only in the epilimnion. By now, the temperature regime in the study lakes seems optimal for $L$. arcticus production and all the lakes are stratified with cold profundal refuges. Not even the projected increase in temperature towards 2100 might be detrimental to L. arcticus in these lakes. In Lake Sandvatn the maximum temperature in the study period was $19.8^{\circ} \mathrm{C}$ (26 July 2006). Comparatively, the maximum temperature for Lake Dragøyfjorden and Lake Dargesjåen was $16.0^{\circ} \mathrm{C}\left(28\right.$ July 2014 ) and $18.4^{\circ} \mathrm{C}$ (28 July 2013), respectively.

However, many lakes on Hardangervidda are shallow with maximum depths well below $10 \mathrm{~m}$. Protracted periods of warm days may be problematic in such localities. Lepidurus arcticus has shown to be an exception in small and shallow lakes and ponds on the Norwegian mainland (Sømme 1934). Most likely the environmental conditions in such localities are too variable and lack the necessary refuges to achieve a successful survival. Both temperature and acid water may be detrimental (Lakka 2013).

In agriculture, the number of days with mean temperature $>5^{\circ} \mathrm{C}$ is used as an indicator of the length of the growing season (Hanssen-Bauer et al. 2017). In the mountains the growing season is currently short ( $<60$ days) but towards year 2100 the thermal growing season is projected to be doubled. Elevated summer temperatures may extend the ice-free period and hence the production period of aquatic organisms. In Lake Øvre Heimdalsvatn however, a 9 days delay in freeze-up, an almost equivalent later ice break-up ( 6 days) left the duration of the icefree period almost unchanged in the study period (Kvambekk \& Melvold 2010).

A lake with water temperature at a higher level and a protracted ice-free period, the thermal input will be substantially increased. This may be a problem even without reaching critical levels by inducing life cycle mismatches. In the laboratory, eggs used at least 700-800 degree-days until hatching (Borgstrøm \& Larsson 1974). It is reasonable to assume that the eggs will hatch far too early in a new temperature regime at a higher level giving a mismatch to the next season. Thus, the unknown upper thermal threshold should not be exceeded for a long period without consequences.

A cold adapted species may suffer local extinction due to physiological effects of increased temperature (Lindholm et al, 2012; 2015). Ectotherms are adapted to certain "temperature windows" both in terms of physiological adaptions, timing and fulfilment of their life cycles (Lindholm et al. 2012). These "temperature windows" should be given according to the lower and upper thermal thresholds. Hence, unsuccessful adaption to extended growing seasons may also result in life cycle mismatches and comprehensive range retractions. 


\section{ACKNOWLEDGEMENTS}

The authors gratefully acknowledge the Norwegian Environment Agency and Laagefjeld AS for financial support. A special thank is given to Herman Stakseng, Gunnar Elnan, Georg Gjøstein, Ove Gåsdal, Stein Lier-Hansen, Halvor Nordjordet and Jarle Nordjordet for valuable assistance in the field, to Jon Museth and Sven E. Gabrielsen for help with the temperature loggers and to Roar Kiær for help with drawing the maps. Two anonymous referees are acknowledged for critically reading and commenting on the manuscript. We will also thank Marte Qvenild for improving the English.

\section{REFERENCES}

Anonymous 1974. Hardangervidda. Natur - Kulturhistorie Samfunnsliv. Miljøverndepartementet (NOU: Norges offentlige utredninger). 1974:30 B. 352 pp. (In Norwegian).

Aass P. 1969. Crustacea, especially Lepidurus arcticus Pallas, as brown trout food in Norwegian mountain reservoirs. Institute of Freshwater Research, Drottningholm. Report No 49, 1969: 183-201.

Arnold GP. 1966. Observations on Lepidurus arcticus (Pallas) (Crustacea, Notostraca) in east Greenland. Annals and Magazine of Natural History 9: 599-617.

Borgstrøm R. 1970. Skjoldkreps, Lepidurus arcticus, i Stolsvannsmagasinet i Hallingdal. Fauna 23: 12-20. (In Norwegian with an English summary).

Borgstrøm R. 2001. Relationship between Spring Snow Depth and Growth of Brown Trout; Salmo trutta, in an Alpine Lake: Predicting Consequences of Climate Change. Arctic, Antarctic, and Alpine Research, Vol. 33, No. 4: 476-480.

Borgstrøm R. 2016. Auren på Hardangervidda er sterkt påverka av klimatilhøve. Naturen nr. 4-2016: 147-155. (In Norwegian). doi: 10.18261/issn. 1504-3118-2016-04-02

Borgstrøm R, Hendrey GR. 1976. pH tolerance of the first larval stages of Lepidurus arcticus (Pallas) and adult Gammarus lacustris G.O.Sars. Sur nedbørs virkning på skog og fisk (SNSFprosjektet), Oslo-Ås, Norway. IR 22/76. 37 pp. (In Norwegian with an English summary).

Borgstrøm R, Larsson P. 1974. The first three instars of Lepidurus arcticus (Pallas) (Crustacea: Notostraca). Norwegian Journal of Zoology 22: 45-52.

Borgstrøm R, Garnås E, Saltveit SJ. 1985. Interactions between brown trout, Salmo trutta L., and minnow, Phoxinus phoxinus (L.) for their common prey, Lepidurus arcticus (Pallas). Verhandlungen des Internationalen Verein Limnologie. 22: 2548-2552.

Borgstrøm R, Museth J. 2005. Accumulated snow and summer temperature - critical factors for recruitment to high mountain populations of brown trout (Salmo trutta L.). Ecology of Freshwater Fish 14: 375-384. doi: 10.1111/j.16000633.2005.00112.x

Dahl K. 1917. Ørret og ørretvann. Studier og forsøk (new edition in 1943). J.W.Cappelens forlag. 182 pp. (In Norwegian).

Fjellheim A, Raddum G. 1990. Acid precipitation: Biological monitoring of streams and lakes. The Science of the Total Environment, 96 (1990): 57-66.

Fjellheim A, Tysse Å, Bjerknes W. 2001. Reappearance of highly acid sensitive invertebrates after liming of an alpine lake ecosystem. Water, Air and Soil Pollution 130: 1391-1396.

Fjellheim A, Tysse $\AA$, Bjerknes W. 2007. Fish Stomachs as a Biomonitoring Tool in Studies of Invertebrate Recovery. Water, Air and Soil Pollution 7: 293-300. doi: 10.1007/s11267-0069074-x

Halvorsen G. 1973. Crustacea from the High Mountain Area Hardangervidda, South Norway. Reports from the High Mountain Ecology Research Station, Finse, Norway. University in Oslo. 1973:2. 17 pp.

Hanssen-Bauer I, Førland EJ, Haddeland I, Hisdal H, Lawrence D, Mayer S, Nesje A, Nilsen JEØ, Sandven S, Sandø AB, Sorteberg A, Ådlandsvik B. 2017. Climate in Norway 2100 - a knowledge base for climate adaption. The Norwegian Center for Climate Services (NCCS). Report no. 1/2017. 45 pp.

Hessen D, Rueness EK, Stabell M. 2004. Circumpolar analysis of morphological and genetic diversity in the Notostracan Lepidurus arcticus. Hydrobiologia 519: 73-84.

Jeppesen E, Christoffersen K, Landkildehus F, Lauridsen T, Amsinck SL, Riget F, Søndergaard M. 2001. Fish and crustaceans in northeast Greenland lakes with special emphasis on interactions between Arctic char (Salvelinus alpinus), Lepidurus arcticus and benthic chydorids. Hydrobiologia 442: 329-337.

Klausen TR. 2012. Population regulation in the tadpole shrimp Lepidurus arcticus. MS-thesis, Norwegian University of Science and Technology, Department of Biology. 25 pp.

Kvambekk AS, Melvold K. 2010. Long-term trends in water temperature and ice cover in the subalpine lake, Øvre Heimdalsvatn, and nearby lakes and rivers. Hydrobiologia (2010) 642: 47-60. doi: 10.1007/s10750-010-0158-2

Lakka H-K. 2013.The ecology of a freshwater crustacean: Lepidurus arcticus (Branchiopoda, Notostraca) in a high Arctic region. The University Centre in Svalbard, Department of High Arctic Biology. MS Thesis. 151 pp.

Lien L. 1978. The energy budget of the brown trout population of Øvre Heimdalsvatn. Holarctic Ecology 1: 279-300.

Lindholm M, Stordal F, Hessen DO, Moe SJ, Aass P. 2012. Climate driven range retraction of an Arctic freshwater crustacean. Freshwater Biology 57: 2591-2601. doi: 10.1111/fwb.12030

Lindholm M, Hessen DO, Færøvig PJ, Rognerud B, Andersen T, Stordal F. 2015. Is distribution of cold stenotherms constrained by temperature? The case of the Arctic fairy shrimp (Branchinecta palludosa O.F.Müller 1788). Journal of Thermal Biology 53 (2015): 46-52. doi: 10.1016/j.jtherbio.2015.08.005

Miller MC. 1980. Tadpole Shrimp. In Taube EB (Edit.). Ecosystems of the World 23 - Lakes and Reservoirs. Elsevier, Amsterdam. 323:339.

Nordli PØ, Lie Ø, Nesje A, Dahl SO. 2003. Spring-summer temperature reconstruction in western Norway 1734-2003: A data-synthesis approach. International Journal of Climatology 23: 1821-1841. doi: 10.1002/joc. 980

Pedersen K, Scobie L. 1990. Dynamikk, habitatbruk og redskapsseleksjon for ørretbestanden i Kollsvatn, en innsjø på Hardangervidda. Norges landbrukshøgskole, Institutt for biologi og naturforvaltning. MS-thesis. 59 pp. (In Norwegian). 
Qvenild T. 2004. Hardangervidda. Fiske og fjelliv. Naturforlaget. 406 pp. (In Norwegian).

Qvenild T, Rognerud S. 2018. Ørreten på Hardangervidda. Klimaets betydning for årsklassestyrke og produksjon av fisk og næringsdyr i Sandvatn 2001-2017. Norsk institutt for vannforskning. Rapport LNR 7267-2018. 34 pp. (In Norwegian with an English summary).

Simonsen TAA, Valderhaug NA. 1994. Bestandsdynamikk, habitatbruk og ernæring for aure i Litlosvatn - ein innsjø på Hardangervidda. Norges landbrukshøgskole, Institutt for biologi og naturforvaltning. MS-thesis. 65 pp. (In Norwegian).

Sømme S. 1934. Contributions to the biology of Norwegian fish food animals. I. Lepidurus arcticus Pallas. Avhandlinger utgitt av det Norske Videnskaps Akademi i Oslo. I. Matem.-Naturvid. Klasse 1934. No 6: 1-36.

Sømme ID. 1941. Ørretboka. Jacob Dybwads Forlag. Oslo (1941). 591 pp. (In Norwegian).

Thaulow J, Haugen TO, Borgstrøm R. 2017. Parallelism in thermal growth response in otoliths and scales of brown trout (Salmo trutta L.) from alpine lakes independent of genetic background. Ecology of Freshwater Fish 26: 53-65. doi: 10.1111/eff.12250

Økland J, Økland KA. 2003. Skjoldkrepsen Lepidurus arcticus i Norge - historikk og utbredelse. Fauna 56 (1) 2003: 2-12. (In Norwegian with an English summary).

Editorial responsibility: Torkild Bakken.

This article is open-access and distributed under the terms of the Creative Commons Attribution 4.0 International license. This permits all non-commercial use, distribution, and reproduction in any medium, provided the original work is properly cited.

(http://creativecommons.org/licenses/by/4.0/). 
Appendix 1. The total sample of brown trout $\geq 250 \mathrm{~mm}(\mathrm{~N}=4460)$ from the six study lakes.

\begin{tabular}{|c|c|c|c|c|c|c|c|}
\hline Lake & $\begin{array}{l}\text { Date of fishing } \\
\text { events }\end{array}$ & $\begin{array}{l}\text { Degree- } \\
\text { days } \geq 4^{\circ} \mathrm{C}\end{array}$ & $\begin{array}{l}\text { No fish } \\
\geq 250 \mathrm{~mm}\end{array}$ & $\begin{array}{l}\text { No of fish with } \\
\text { L. arcticus }\end{array}$ & Frequency $\%$ & $\begin{array}{l}\text { Average size } \\
(\min -\max ) \mathrm{mm}\end{array}$ & Fishing method \\
\hline Blånuttjørn & 18.06 .04 & 31 & 9 & 0 & $0 \%$ & $361(287-485)$ & Test-fishing \\
\hline Blånuttjørn & 17.08 .04 & 679 & 12 & 2 & $17 \%$ & $285(250-345)$ & Test-fishing \\
\hline Dargesjåen & 10.08 .03 & 641 & 32 & 12 & $38 \%$ & $309(250-390)$ & Test-fishing \\
\hline Dargesjåen & 13.08 .03 & 688 & 6 & 3 & $50 \%$ & $326(285-365)$ & Test-fishing \\
\hline Dargesjåen & 14.08 .03 & 701 & 25 & 23 & $92 \%$ & $353(300-405)$ & Test-fishing \\
\hline Dargesjåen & 17.06 .04 & 56 & 13 & 0 & $0 \%$ & $291(250-367)$ & Test-fishing \\
\hline Dargesjåen & 28.06 .07 & 101 & 25 & 0 & $0 \%$ & $314(255-433)$ & Test-fishing \\
\hline Dargesjåen & 29.09 .07 & 965 & 13 & 2 & $15 \%$ & $297(252-372)$ & Test-fishing \\
\hline Dargesjåen & 29.09.11 & 1241 & 12 & 4 & $33 \%$ & $334(301-365)$ & Test-fishing \\
\hline Dargesjåen & 28.09.12 & 870 & 19 & 1 & $5 \%$ & $391(251-757)$ & Test-fishing \\
\hline Dragøyfjorden & 02.08 .06 & 404 & 35 & 0 & $0 \%$ & No data & Commercial catch \\
\hline Dragøyfjorden & 03.08 .06 & 419 & 9 & 2 & $22 \%$ & No data & Commercial catch \\
\hline Dragøyfjorden & 04.08 .06 & 433 & 8 & 0 & $0 \%$ & No data & Commercial catch \\
\hline Dragøyfjorden & 05.08 .06 & 449 & 12 & 0 & $0 \%$ & No data & Commercial catch \\
\hline Dragøyfjorden & 06.08 .06 & 464 & 9 & 0 & $0 \%$ & No data & Commercial catch \\
\hline Dragøyfjorden & 07.08 .06 & 478 & 3 & 0 & $0 \%$ & No data & Commercial catch \\
\hline Dragøyfjorden & 08.08 .06 & 493 & 9 & 0 & $0 \%$ & No data & Commercial catch \\
\hline Dragøyfjorden & 20.08 .06 & 654 & 9 & 0 & $0 \%$ & No data & Commercial catch \\
\hline Dragøyfjorden & 21.08 .06 & 668 & 12 & 4 & $33 \%$ & No data & Commercial catch \\
\hline Dragøyfjorden & 28.08 .06 & 761 & 28 & 10 & $36 \%$ & No data & Commercial catch \\
\hline Dragøyfjorden & 29.08 .06 & 773 & 10 & 5 & $50 \%$ & No data & Commercial catch \\
\hline Dragøyfjorden & 10.09 .06 & 905 & 29 & 16 & $55 \%$ & No data & Commercial catch \\
\hline Dragøyfjorden & 11.09 .06 & 915 & 18 & 13 & $72 \%$ & No data & Commercial catch \\
\hline Dragøyfjorden & 15.09 .06 & 955 & 20 & 10 & $50 \%$ & No data & Commercial catch \\
\hline Dragøyfjorden & 02.08 .08 & 282 & 20 & 0 & $0 \%$ & No data & Commercial catch \\
\hline Dragøyfjorden & 03.08 .08 & 295 & 4 & 0 & $0 \%$ & No data & Commercial catch \\
\hline Dragøyfjorden & 04.08 .08 & 308 & 10 & 0 & $0 \%$ & No data & Commercial catch \\
\hline Dragøyfjorden & 05.08 .08 & 321 & 12 & 0 & $0 \%$ & No data & Commercial catch \\
\hline Dragøyfjorden & 06.08 .08 & 333 & 15 & 0 & $0 \%$ & No data & Commercial catch \\
\hline Dragøyfjorden & 07.08 .08 & 346 & 3 & 0 & $0 \%$ & No data & Commercial catch \\
\hline Dragøyfjorden & 08.08 .08 & 358 & 7 & 0 & $0 \%$ & No data & Commercial catch \\
\hline Dragøyfjorden & 13.08 .08 & 417 & 6 & 0 & $0 \%$ & No data & Commercial catch \\
\hline Dragøyfjorden & 14.08 .08 & 428 & 4 & 0 & $0 \%$ & No data & Commercial catch \\
\hline Dragøyfjorden & 02.09 .08 & 635 & 25 & 20 & $80 \%$ & No data & Commercial catch \\
\hline Dragøyfjorden & 04.09 .08 & 655 & 8 & 7 & $88 \%$ & No data & Commercial catch \\
\hline Dragøyfjorden & 27.07.09 & 404 & 25 & 1 & $4 \%$ & No data & Commercial catch \\
\hline Dragøyfjorden & 28.07 .09 & 415 & 21 & 1 & $5 \%$ & No data & Commercial catch \\
\hline Dragøyfjorden & 29.07.09 & 426 & 10 & 0 & $0 \%$ & No data & Commercial catch \\
\hline Dragøyfjorden & 30.07 .09 & 437 & 17 & 2 & $12 \%$ & No data & Commercial catch \\
\hline Dragøyfjorden & 31.07 .09 & 448 & 11 & 1 & $9 \%$ & No data & Commercial catch \\
\hline Dragøyfjorden & 01.08 .09 & 458 & 9 & 0 & $0 \%$ & No data & Commercial catch \\
\hline Dragøyfjorden & 02.08 .09 & 469 & 14 & 2 & $14 \%$ & No data & Commercial catch \\
\hline
\end{tabular}


Appendix 1. Continued.

\begin{tabular}{|c|c|c|c|c|c|c|c|}
\hline Lake & $\begin{array}{l}\text { Date of fishing } \\
\text { events }\end{array}$ & $\begin{array}{l}\text { Degree- } \\
\text { days } \geq 4^{\circ} \mathrm{C}\end{array}$ & $\begin{array}{l}\text { No fish } \\
\geq 250 \mathrm{~mm}\end{array}$ & $\begin{array}{l}\text { No of fish with } \\
\text { L. arcticus }\end{array}$ & Frequency $\%$ & $\begin{array}{l}\text { Average size } \\
(\min -\max ) \mathrm{mm}\end{array}$ & Fishing method \\
\hline Dragøyfjorden & 03.08.09 & 479 & 13 & 1 & $8 \%$ & No data & Commercial catch \\
\hline Dragøyfjorden & 04.08 .09 & 490 & 10 & 0 & $0 \%$ & No data & Commercial catch \\
\hline Dragøyfjorden & 11.08 .09 & 570 & 2 & 1 & $50 \%$ & No data & Commercial catch \\
\hline Dragøyfjorden & 12.08 .09 & 582 & 2 & 2 & $100 \%$ & No data & Commercial catch \\
\hline Dragøyfjorden & 25.08 .09 & 719 & 33 & 31 & $94 \%$ & No data & Commercial catch \\
\hline Dragøyfjorden & 26.08 .09 & 730 & 26 & 23 & $88 \%$ & No data & Commercial catch \\
\hline Dragøyfjorden & 27.08 .09 & 740 & 14 & 11 & $79 \%$ & No data & Commercial catch \\
\hline Dragøyfjorden & 28.08 .09 & 750 & 24 & 19 & $79 \%$ & No data & Commercial catch \\
\hline Dragøyfjorden & 07.09.09 & 841 & 22 & 20 & $91 \%$ & No data & Commercial catch \\
\hline Dragøyfjorden & 27.07 .10 & 360 & 36 & 0 & $0 \%$ & No data & Commercial catch \\
\hline Dragøyfjorden & 28.07.10 & 372 & 16 & 0 & $0 \%$ & No data & Commercial catch \\
\hline Dragøyfjorden & 29.07 .10 & 384 & 17 & 0 & $0 \%$ & No data & Commercial catch \\
\hline Dragøyfjorden & 30.07 .10 & 398 & 34 & 0 & $0 \%$ & No data & Commercial catch \\
\hline Dragøyfjorden & 31.07 .10 & 408 & 18 & 0 & $0 \%$ & No data & Commercial catch \\
\hline Dragøyfjorden & 01.08 .10 & 420 & 26 & 0 & $0 \%$ & No data & Commercial catch \\
\hline Dragøyfjorden & 02.08 .10 & 432 & 8 & 0 & $0 \%$ & No data & Commercial catch \\
\hline Dragøyfjorden & 03.08 .10 & 444 & 8 & 2 & $25 \%$ & No data & Commercial catch \\
\hline Dragøyfjorden & 04.08 .10 & 456 & 9 & 0 & $0 \%$ & No data & Commercial catch \\
\hline Dragøyfjorden & 05.08 .10 & 469 & 6 & 0 & $0 \%$ & No data & Commercial catch \\
\hline Dragøyfjorden & 06.08 .10 & 481 & 7 & 0 & $0 \%$ & No data & Commercial catch \\
\hline Dragøyfjorden & 20.08 .10 & 657 & 26 & 17 & $65 \%$ & No data & Commercial catch \\
\hline Dragøyfjorden & 21.08 .10 & 669 & 25 & 16 & $64 \%$ & No data & Commercial catch \\
\hline Dragøyfjorden & 22.08 .10 & 681 & 12 & 8 & $67 \%$ & No data & Commercial catch \\
\hline Dragøyfjorden & 04.09 .10 & 816 & 42 & 22 & $52 \%$ & No data & Commercial catch \\
\hline Dragøyfjorden & 05.09 .10 & 826 & 28 & 12 & $43 \%$ & No data & Commercial catch \\
\hline Dragøyfjorden & 06.09 .10 & 836 & 19 & 15 & $79 \%$ & No data & Commercial catch \\
\hline Dragøyfjorden & 07.09 .10 & 846 & 25 & 20 & $80 \%$ & No data & Commercial catch \\
\hline Dragøyfjorden & 02.07 .11 & 67 & 23 & 0 & $0 \%$ & No data & Commercial catch \\
\hline Dragøyfjorden & 04.07 .11 & 74 & 23 & 0 & $0 \%$ & No data & Commercial catch \\
\hline Dragøyfjorden & 05.07 .11 & 81 & 11 & 0 & $0 \%$ & No data & Commercial catch \\
\hline Dragøyfjorden & 12.07.11 & 148 & 10 & 0 & $0 \%$ & No data & Commercial catch \\
\hline Dragøyfjorden & 13.07 .11 & 157 & 3 & 0 & $0 \%$ & No data & Commercial catch \\
\hline Dragøyfjorden & 14.07 .11 & 167 & 3 & 0 & $0 \%$ & No data & Commercial catch \\
\hline Dragøyfjorden & 23.07 .11 & 260 & 21 & 0 & $0 \%$ & No data & Commercial catch \\
\hline Dragøyfjorden & 24.07 .11 & 271 & 14 & 0 & $0 \%$ & No data & Commercial catch \\
\hline Dragøyfjorden & 25.07 .11 & 281 & 7 & 0 & $0 \%$ & No data & Commercial catch \\
\hline Dragøyfjorden & 26.07 .11 & 292 & 11 & 0 & $0 \%$ & No data & Commercial catch \\
\hline Dragøyfjorden & 27.07 .11 & 303 & 12 & 0 & $0 \%$ & No data & Commercial catch \\
\hline Dragøyfjorden & 10.08 .11 & 487 & 20 & 0 & $0 \%$ & No data & Commercial catch \\
\hline Dragøyfjorden & 11.08 .11 & 499 & 16 & 1 & $6 \%$ & No data & Commercial catch \\
\hline Dragøyfjorden & 12.08 .11 & 511 & 12 & 2 & $17 \%$ & No data & Commercial catch \\
\hline Dragøyfjorden & 13.08 .11 & 523 & 22 & 10 & $45 \%$ & No data & Commercial catch \\
\hline
\end{tabular}


Appendix 1. Continued.

\begin{tabular}{|c|c|c|c|c|c|c|c|}
\hline Lake & $\begin{array}{l}\text { Date of fishing } \\
\text { events }\end{array}$ & $\begin{array}{l}\text { Degree- } \\
\text { days } \geq 4^{\circ} \mathrm{C}\end{array}$ & $\begin{array}{l}\text { No fish } \\
\geq 250 \mathrm{~mm}\end{array}$ & $\begin{array}{l}\text { No of fish with } \\
\text { L. arcticus }\end{array}$ & Frequency $\%$ & $\begin{array}{l}\text { Average size } \\
(\min -\max ) \mathrm{mm}\end{array}$ & Fishing method \\
\hline Dragøyfjorden & 20.08 .11 & 604 & 13 & 10 & $77 \%$ & No data & Commercial catch \\
\hline Dragøyfjorden & 21.08 .11 & 615 & 11 & 5 & $45 \%$ & No data & Commercial catch \\
\hline Dragøyfjorden & 01.09 .11 & 731 & 33 & 15 & $45 \%$ & No data & Commercial catch \\
\hline Dragøyfjorden & 02.09 .11 & 741 & 18 & 11 & $61 \%$ & No data & Commercial catch \\
\hline Dragøyfjorden & 03.09 .11 & 752 & 29 & 16 & $55 \%$ & No data & Commercial catch \\
\hline Dragøyfjorden & 09.09.11 & 810 & 27 & 15 & $56 \%$ & No data & Commercial catch \\
\hline Dragøyfjorden & 15.09 .11 & 863 & 34 & 16 & $47 \%$ & No data & Commercial catch \\
\hline Dragøyfjorden & 07.07 .12 & 4 & 33 & 0 & $0 \%$ & No data & Commercial catch \\
\hline Dragøyfjorden & 08.07 .12 & 8 & 21 & 0 & $0 \%$ & No data & Commercial catch \\
\hline Dragøyfjorden & 09.07.12 & 12 & 23 & 0 & $0 \%$ & No data & Commercial catch \\
\hline Dragøyfjorden & 12.07 .12 & 25 & 40 & 0 & $0 \%$ & No data & Commercial catch \\
\hline Dragøyfjorden & 14.07.12 & 36 & 37 & 0 & $0 \%$ & No data & Commercial catch \\
\hline Dragøyfjorden & 22.07 .12 & 89 & 29 & 0 & $0 \%$ & No data & Commercial catch \\
\hline Dragøyfjorden & 23.07 .12 & 96 & 15 & 0 & $0 \%$ & No data & Commercial catch \\
\hline Dragøyfjorden & 02.08 .12 & 183 & 22 & 0 & $0 \%$ & No data & Commercial catch \\
\hline Dragøyfjorden & 03.08.12 & 192 & 9 & 0 & $0 \%$ & No data & Commercial catch \\
\hline Dragøyfjorden & 04.08 .12 & 202 & 18 & 0 & $0 \%$ & No data & Commercial catch \\
\hline Dragøyfjorden & 05.08 .12 & 212 & 7 & 0 & $0 \%$ & No data & Commercial catch \\
\hline Dragøyfjorden & 20.08 .12 & 372 & 25 & 8 & $32 \%$ & No data & Commercial catch \\
\hline Dragøyfjorden & 21.08 .12 & 384 & 24 & 5 & $21 \%$ & No data & Commercial catch \\
\hline Dragøyfjorden & 22.08 .12 & 395 & 19 & 1 & $5 \%$ & No data & Commercial catch \\
\hline Dragøyfjorden & 10.09 .12 & 572 & 51 & 32 & $63 \%$ & No data & Commercial catch \\
\hline Dragøyfjorden & 11.09 .12 & 579 & 27 & 17 & $63 \%$ & No data & Commercial catch \\
\hline Dragøyfjorden & 02.07 .13 & 99 & 37 & 0 & $0 \%$ & No data & Commercial catch \\
\hline Dragøyfjorden & 03.07 .13 & 106 & 22 & 0 & $0 \%$ & No data & Commercial catch \\
\hline Dragøyfjorden & 04.07.13 & 114 & 19 & 0 & $0 \%$ & No data & Commercial catch \\
\hline Dragøyfjorden & 05.07 .13 & 122 & 23 & 0 & $0 \%$ & No data & Commercial catch \\
\hline Dragøyfjorden & 20.07 .13 & 265 & 32 & 0 & $0 \%$ & No data & Commercial catch \\
\hline Dragøyfjorden & 21.07 .13 & 276 & 25 & 0 & $0 \%$ & No data & Commercial catch \\
\hline Dragøyfjorden & 22.07 .13 & 289 & 11 & 0 & $0 \%$ & No data & Commercial catch \\
\hline Dragøyfjorden & 26.07 .13 & 342 & 9 & 0 & $0 \%$ & No data & Commercial catch \\
\hline Dragøyfjorden & 30.07 .13 & 394 & 8 & 0 & $0 \%$ & No data & Commercial catch \\
\hline Dragøyfjorden & 02.08 .13 & 432 & 18 & 2 & $11 \%$ & No data & Commercial catch \\
\hline Dragøyfjorden & 03.08 .13 & 444 & 17 & 1 & $6 \%$ & No data & Commercial catch \\
\hline Dragøyfjorden & 04.08 .13 & 457 & 9 & 4 & $44 \%$ & No data & Commercial catch \\
\hline Dragøyfjorden & 05.09 .13 & 811 & 74 & 54 & $73 \%$ & No data & Commercial catch \\
\hline Dragøyfjorden & 06.09 .13 & 821 & 37 & 33 & $89 \%$ & No data & Commercial catch \\
\hline Dragøyfjorden & 13.09 .13 & 892 & 24 & 7 & $29 \%$ & No data & Commercial catch \\
\hline Dragøyfjorden & 14.09 .13 & 902 & 32 & 28 & $88 \%$ & No data & Commercial catch \\
\hline Dragøyfjorden & 15.09 .13 & 912 & 22 & 21 & $95 \%$ & No data & Commercial catch \\
\hline Dragøyfjorden & 02.07 .14 & 97 & 22 & 0 & $0 \%$ & No data & Commercial catch \\
\hline Dragøyfjorden & 03.07 .14 & 106 & 27 & 0 & $0 \%$ & No data & Commercial catch \\
\hline Dragøyfjorden & 04.07 .14 & 115 & 12 & 0 & $0 \%$ & No data & Commercial catch \\
\hline
\end{tabular}


Appendix 1. Continued.

\begin{tabular}{|c|c|c|c|c|c|c|c|}
\hline Lake & $\begin{array}{l}\text { Date of fishing } \\
\text { events }\end{array}$ & $\begin{array}{l}\text { Degree- } \\
\text { days } \geq 4^{\circ} \mathrm{C}\end{array}$ & $\begin{array}{l}\text { No fish } \\
\geq 250 \mathrm{~mm}\end{array}$ & $\begin{array}{l}\text { No of fish with } \\
\text { L. arcticus }\end{array}$ & Frequency $\%$ & $\begin{array}{l}\text { Average size } \\
\text { (min-max) mm }\end{array}$ & Fishing method \\
\hline Dragøyfjorden & 05.07 .14 & 123 & 14 & 0 & $0 \%$ & No data & Commercial catch \\
\hline Dragøyfjorden & 06.07 .14 & 132 & 12 & 0 & $0 \%$ & No data & Commercial catch \\
\hline Dragøyfjorden & 15.07 .14 & 231 & 7 & 0 & $0 \%$ & No data & Commercial catch \\
\hline Dragøyfjorden & 31.07 .14 & 461 & 26 & 0 & $0 \%$ & No data & Commercial catch \\
\hline Dragøyfjorden & 01.08 .14 & 476 & 23 & 0 & $0 \%$ & No data & Commercial catch \\
\hline Dragøyfjorden & 02.08 .14 & 491 & 7 & 0 & $0 \%$ & No data & Commercial catch \\
\hline Dragøyfjorden & 03.08.14 & 505 & 14 & 0 & $0 \%$ & No data & Commercial catch \\
\hline Dragøyfjorden & 08.08 .14 & 576 & 13 & 0 & $0 \%$ & No data & Commercial catch \\
\hline Dragøyfjorden & 09.08.14 & 591 & 14 & 0 & $0 \%$ & No data & Commercial catch \\
\hline Dragøyfjorden & 12.08 .14 & 630 & 17 & 0 & $0 \%$ & No data & Commercial catch \\
\hline Dragøyfjorden & 22.08 .14 & 747 & 25 & 11 & $44 \%$ & No data & Commercial catch \\
\hline Dragøyfjorden & 23.08 .14 & 758 & 29 & 13 & $45 \%$ & No data & Commercial catch \\
\hline Dragøyfjorden & 29.08 .14 & 823 & 27 & 20 & $74 \%$ & No data & Commercial catch \\
\hline Dragøyfjorden & 30.08 .14 & 834 & 29 & 17 & $59 \%$ & No data & Commercial catch \\
\hline Dragøyfjorden & 31.08 .14 & 844 & 11 & 4 & $36 \%$ & No data & Commercial catch \\
\hline Dragøyfjorden & 06.09 .14 & 906 & 9 & 0 & $0 \%$ & No data & Commercial catch \\
\hline Dragøyfjorden & 15.09.14 & 999 & 26 & 18 & $69 \%$ & No data & Commercial catch \\
\hline Dragøyfjorden & 11.07 .15 & - & 6 & 0 & $0 \%$ & No data & Commercial catch \\
\hline Dragøyfjorden & 14.07 .15 & - & 4 & 0 & $0 \%$ & No data & Commercial catch \\
\hline Dragøyfjorden & 18.07.15 & - & 19 & 0 & $0 \%$ & No data & Commercial catch \\
\hline Dragøyfjorden & 22.07 .15 & 17 & 14 & 0 & $0 \%$ & No data & Commercial catch \\
\hline Dragøyfjorden & 24.07 .15 & 27 & 24 & 0 & $0 \%$ & No data & Commercial catch \\
\hline Dragøyfjorden & 25.07 .15 & 31 & 14 & 0 & $0 \%$ & No data & Commercial catch \\
\hline Dragøyfjorden & 30.07 .15 & 60 & 10 & 0 & $0 \%$ & No data & Commercial catch \\
\hline Dragøyfjorden & 31.07 .15 & 66 & 17 & 0 & $0 \%$ & No data & Commercial catch \\
\hline Dragøyfjorden & 01.08 .15 & 73 & 11 & 0 & $0 \%$ & No data & Commercial catch \\
\hline Dragøyfjorden & 02.08 .15 & 79 & 16 & 0 & $0 \%$ & No data & Commercial catch \\
\hline Dragøyfjorden & 06.08 .15 & 106 & 9 & 0 & $0 \%$ & No data & Commercial catch \\
\hline Dragøyfjorden & 07.08 .15 & 113 & 12 & 0 & $0 \%$ & No data & Commercial catch \\
\hline Dragøyfjorden & 08.08 .15 & 121 & 17 & 0 & $0 \%$ & No data & Commercial catch \\
\hline Dragøyfjorden & 09.08 .15 & 128 & 11 & 0 & $0 \%$ & No data & Commercial catch \\
\hline Dragøyfjorden & 13.08 .15 & 159 & 5 & 0 & $0 \%$ & No data & Commercial catch \\
\hline Dragøyfjorden & 16.08 .15 & 185 & 6 & 0 & $0 \%$ & No data & Commercial catch \\
\hline Dragøyfjorden & 09.09 .15 & 401 & 15 & 3 & $20 \%$ & No data & Commercial catch \\
\hline Dragøyfjorden & 02.07 .16 & 27 & 16 & 0 & $0 \%$ & No data & Commercial catch \\
\hline Dragøyfjorden & 03.07 .16 & 32 & 13 & 0 & $0 \%$ & No data & Commercial catch \\
\hline Dragøyfjorden & 04.07 .16 & 38 & 8 & 0 & $0 \%$ & No data & Commercial catch \\
\hline Dragøyfjorden & 05.07 .16 & 44 & 8 & 0 & $0 \%$ & No data & Commercial catch \\
\hline Dragøyfjorden & 22.07 .16 & 191 & 7 & 0 & $0 \%$ & No data & Commercial catch \\
\hline Dragøyfjorden & 23.07.16 & 202 & 13 & 0 & $0 \%$ & No data & Commercial catch \\
\hline Dragøyfjorden & 24.07.16 & 214 & 14 & 0 & $0 \%$ & No data & Commercial catch \\
\hline Dragøyfjorden & 25.07.16 & 225 & 13 & 0 & $0 \%$ & No data & Commercial catch \\
\hline Dragøyfjorden & 04.08 .16 & 332 & 14 & 0 & $0 \%$ & No data & Commercial catch \\
\hline
\end{tabular}


Appendix 1. Continued.

\begin{tabular}{|c|c|c|c|c|c|c|c|}
\hline Lake & $\begin{array}{l}\text { Date of fishing } \\
\text { events }\end{array}$ & $\begin{array}{l}\text { Degree- } \\
\text { days } \geq 4^{\circ} \mathrm{C}\end{array}$ & $\begin{array}{l}\text { No fish } \\
\geq 250 \mathrm{~mm}\end{array}$ & $\begin{array}{l}\text { No of fish with } \\
\text { L. arcticus }\end{array}$ & Frequency $\%$ & $\begin{array}{l}\text { Average size } \\
\text { (min-max) } \mathrm{mm}\end{array}$ & Fishing method \\
\hline Dragøyfjorden & 07.08 .16 & 363 & 13 & 1 & $8 \%$ & No data & Commercial catch \\
\hline Dragøyfjorden & 11.08 .16 & 401 & 12 & 1 & $8 \%$ & No data & Commercial catch \\
\hline Dragøyfjorden & 12.08 .16 & 409 & 11 & 7 & $64 \%$ & No data & Commercial catch \\
\hline Dragøyfjorden & 21.08.16 & 497 & 15 & 8 & $53 \%$ & No data & Commercial catch \\
\hline Fjellsjåen & 02.10 .06 & 1287 & 50 & 42 & $84 \%$ & $413(308-490)$ & Test-fishing \\
\hline Fjellsjåen & 27.06 .07 & 69 & 35 & 0 & $0 \%$ & $347(255-520)$ & Test-fishing \\
\hline Fjellsjåen & 29.09 .07 & 962 & 29 & 28 & $97 \%$ & $405(255-495)$ & Test-fishing \\
\hline Fjellsjåen & 29.09 .08 & 1113 & 31 & 23 & $74 \%$ & $399(250-507)$ & Test-fishing \\
\hline Fjellsjåen & 21.06.09 & 46 & 22 & 0 & $0 \%$ & $379(250-484)$ & Test-fishing \\
\hline Fjellsjåen & 02.10 .09 & 1153 & 33 & 9 & $27 \%$ & $381(252-485)$ & Test-fishing \\
\hline Fjellsjåen & 26.06 .10 & 79 & 21 & 0 & $0 \%$ & $380(258-495)$ & Test-fishing \\
\hline Fjellsjåen & 29.09 .10 & 1085 & 21 & 5 & $24 \%$ & $359(250-465)$ & Test-fishing \\
\hline Fjellsjåen & 29.09 .11 & 1313 & 44 & 7 & $16 \%$ & $355(250-520)$ & Test-fishing \\
\hline Fjellsjåen & 28.09.12 & 883 & 26 & 5 & $19 \%$ & $374(279-525)$ & Test-fishing \\
\hline Kriglesjåen & 06.09 .04 & 936 & 50 & 32 & $64 \%$ & $335(250-490)$ & Test-fishing \\
\hline Kriglesjåen & 07.09 .04 & 945 & 7 & 4 & $57 \%$ & $362(265-560)$ & Test-fishing \\
\hline Sandvatn & 16.08 .04 & 740 & 28 & 0 & $0 \%$ & $296(250-440)$ & Test-fishing \\
\hline Sandvatn & 15.08 .05 & 543 & 21 & 0 & $0 \%$ & $300(250-430)$ & Test-fishing \\
\hline Sandvatn & 16.08 .05 & 555 & 26 & 0 & $0 \%$ & $300(250-410)$ & Test-fishing \\
\hline Sandvatn & 17.08 .05 & 566 & 32 & 1 & $3 \%$ & $311(265-415)$ & Test-fishing \\
\hline Sandvatn & 14.08 .06 & 789 & 32 & 0 & $0 \%$ & $295(250-395)$ & Test-fishing \\
\hline Sandvatn & 16.08 .06 & 816 & 25 & 0 & $0 \%$ & $319(280-390)$ & Test-fishing \\
\hline Sandvatn & 27.06 .07 & 31 & 39 & 0 & $0 \%$ & $294(250-375)$ & Test-fishing \\
\hline Sandvatn & 12.08 .07 & 381 & 52 & 0 & $0 \%$ & $307(250-360)$ & Test-fishing \\
\hline Sandvatn & 13.08 .07 & 394 & 30 & 0 & $0 \%$ & $321(257-380)$ & Test-fishing \\
\hline Sandvatn & 14.08 .07 & 406 & 7 & 0 & $0 \%$ & $290(253-345)$ & Test-fishing \\
\hline Sandvatn & 15.08 .07 & 417 & 88 & 0 & $0 \%$ & $321(260-432)$ & Test-fishing \\
\hline Sandvatn & 30.09 .07 & 746 & 36 & 3 & $8 \%$ & $331(250-390)$ & Test-fishing \\
\hline Sandvatn & 10.08 .08 & 538 & 16 & 0 & $0 \%$ & $293(250-360)$ & Test-fishing \\
\hline Sandvatn & 11.08 .08 & 550 & 14 & 2 & $14 \%$ & $285(250-350)$ & Test-fishing \\
\hline Sandvatn & 13.08 .08 & 574 & 43 & 1 & $2 \%$ & $303(260-385)$ & Test-fishing \\
\hline Sandvatn & 14.08 .08 & 585 & 4 & 1 & $25 \%$ & $341(335-338)$ & Test-fishing \\
\hline Sandvatn & 15.08 .08 & 597 & 12 & 7 & $58 \%$ & $351(322-375)$ & Test-fishing \\
\hline Sandvatn & 28.09 .08 & 1002 & 11 & 0 & $0 \%$ & $289(254-365)$ & Test-fishing \\
\hline Sandvatn & 09.08.09 & 601 & 12 & 0 & $0 \%$ & $307(255-345)$ & Test-fishing \\
\hline Sandvatn & 10.08 .09 & 614 & 4 & 0 & $0 \%$ & $278(250-325)$ & Test-fishing \\
\hline Sandvatn & 11.08 .09 & 627 & 19 & 4 & $21 \%$ & $338(293-385)$ & Test-fishing \\
\hline Sandvatn & 12.08 .09 & 640 & 33 & 2 & $6 \%$ & $317(250-395)$ & Test-fishing \\
\hline Sandvatn & 14.08 .09 & 664 & 21 & 7 & $33 \%$ & $317(272-373)$ & Test-fishing \\
\hline Sandvatn & 26.06 .10 & 95 & 24 & 0 & $0 \%$ & $330(250-380)$ & Test-fishing \\
\hline Sandvatn & 08.08 .10 & 611 & 10 & 0 & $0 \%$ & $312(258-384)$ & Test-fishing \\
\hline Sandvatn & 09.08 .10 & 625 & 9 & 2 & $22 \%$ & $321(267-386)$ & Test-fishing \\
\hline Sandvatn & 10.08 .10 & 639 & 12 & 3 & $25 \%$ & $327(250-428)$ & Test-fishing \\
\hline
\end{tabular}


Appendix 1. Continued.

\begin{tabular}{|c|c|c|c|c|c|c|c|}
\hline Lake & $\begin{array}{l}\text { Date of fishing } \\
\text { events }\end{array}$ & $\begin{array}{l}\text { Degree- } \\
\text { days } \geq 4^{\circ} \mathrm{C}\end{array}$ & $\begin{array}{l}\text { No fish } \\
\geq 250 \mathrm{~mm}\end{array}$ & $\begin{array}{l}\text { No of fish with } \\
\text { L. arcticus }\end{array}$ & Frequency $\%$ & $\begin{array}{l}\text { Average size } \\
\text { (min-max) mm }\end{array}$ & Fishing method \\
\hline Sandvatn & 11.08 .10 & 652 & 13 & 0 & $0 \%$ & $316(258-612)$ & Test-fishing \\
\hline Sandvatn & 30.09 .10 & 1119 & 36 & 0 & $0 \%$ & $295(250-392)$ & Test-fishing \\
\hline Sandvatn & 14.08 .11 & 627 & 9 & 0 & $0 \%$ & $299(252-430)$ & Test-fishing \\
\hline Sandvatn & 15.08 .11 & 639 & 11 & 2 & $18 \%$ & $288(253-390)$ & Test-fishing \\
\hline Sandvatn & 18.08 .11 & 673 & 25 & 2 & $8 \%$ & $324(265-400)$ & Test-fishing \\
\hline Sandvatn & 19.08 .11 & 684 & 15 & 3 & $20 \%$ & $337(273-443)$ & Test-fishing \\
\hline Sandvatn & 30.09 .11 & 1045 & 15 & 0 & $0 \%$ & $300(247-402)$ & Test-fishing \\
\hline Sandvatn & 11.08 .13 & 677 & 5 & 0 & $0 \%$ & $285(255-337)$ & Test-fishing \\
\hline Sandvatn & 12.08 .13 & 688 & 19 & 3 & $16 \%$ & $339(250-440)$ & Test-fishing \\
\hline Sandvatn & 13.08 .13 & 700 & 10 & 1 & $10 \%$ & $302(250-348)$ & Test-fishing \\
\hline Sandvatn & 15.08 .13 & 725 & 5 & 2 & $40 \%$ & $374(276-480)$ & Test-fishing \\
\hline Sandvatn & 10.08 .14 & 603 & 14 & 2 & $14 \%$ & $281(250-470)$ & Test-fishing \\
\hline Sandvatn & 11.08 .14 & 615 & 6 & 1 & $17 \%$ & $304(259-373)$ & Test-fishing \\
\hline Sandvatn & 12.08 .14 & 627 & 5 & 0 & $0 \%$ & $272(259-293)$ & Test-fishing \\
\hline Sandvatn & 09.08 .15 & 259 & 16 & 0 & $0 \%$ & $278(250-325)$ & Test-fishing \\
\hline Sandvatn & 10.08 .15 & 268 & 31 & 0 & $0 \%$ & $319(255-469)$ & Test-fishing \\
\hline Sandvatn & 12.08 .15 & 287 & 59 & 0 & $0 \%$ & $309(250-475)$ & Test-fishing \\
\hline Sandvatn & 14.08 .15 & 307 & 37 & 0 & $0 \%$ & $323(250-485)$ & Test-fishing \\
\hline Sandvatn & 14.08 .16 & 462 & 19 & 4 & $21 \%$ & $304(256-383)$ & Test-fishing \\
\hline Sandvatn & 15.08 .16 & 471 & 17 & 1 & $6 \%$ & $300(252-478)$ & Test-fishing \\
\hline Sandvatn & 17.08 .16 & 480 & 6 & 2 & $33 \%$ & $336(270-470)$ & Test-fishing \\
\hline Sandvatn & 18.08 .16 & 490 & 29 & 3 & $10 \%$ & $297(255-438)$ & Test-fishing \\
\hline
\end{tabular}

